\title{
The Relationship Between Perceptions of Winning and Achievement Goals of Female Basketball Players
}

\author{
Fatma Çepikkurt ${ }^{1}$, Esen Kızıldağ Kale ${ }^{2}$ \\ ${ }^{1}$ School of Physical Education and Sport, Mersin University, Turkey \\ ${ }^{2}$ School of Physical Education and Sport, Nişantaşı University, Turkey \\ Correspondence: Fatma Çepikkurt, School of Physical Education and Sport, Mersin University, Turkey.
}

Received: March 11, 2019

Accepted: March 24, 2019 Online Published: March 27, 2019

doi:10.11114/jets.v7i3S.4132

URL: https://doi.org/10.11114/jets.v7i3S.4132

\begin{abstract}
The aim of this study was to measure the levels of perceptions of winning and determine the achievement goals of female basketball players, and to investigate the relationship between the two. Ninety-two female basketball players between the ages of 16 and $31\left(X_{\text {age }}=19.45 \pm 3.46 ; X_{\text {sportage }}=6.97 \pm 4.64\right)$ participated in this study. In order to measure the participants' perceptions related to winning, the "Perception of Winning Scale", developed by Okur and Güven (2012), was used. The "2x2 Achievement Goals Questionnaire", developed by Conroy et al. (2003) and adapted for Turkish by Kazak Çetinkalp et al. (2009), was used to determine the achievement goals of the participants. Descriptive statistics, Pearson Product-Moment Multiplication Correlation Analysis, and the independent t-test were used to analyse the data. The participants scored high on the Perception of Winning Scale, while their highest mean scores on the $2 \times 2$ Achievement Goals Questionnaire were on the "mastery approach" subscale. Pearson correlation analysis revealed the existence of a statistically significant and positive correlation between winning perception and performance-approach and between winning perception and performance-avoidance. The results of this study indicated that the participating female basketball players perceived winning as being ahead of others, being superior to or not being surpassed by others, and not being behind others. We thus concluded that they attributed winning to external factors.
\end{abstract}

Keywords: winning perception, achievement goal, female basketball players

\section{Introduction}

\subsection{Introduction the Problem}

In recent years, sports scientists have focused on scientific studies on psychological factors related to success in team sports, such as motivation, group cohesion, self-confidence, self-efficacy, leadership etc. (Comeig et al, 2016; Çepikkurt \& Uluöz, 2017; Rottensteiner et al, 2015; Sheehan, Herring \& Campbell, 2018; Success can be defined as accomplishing a desired goal at the desired time and in the manner desired (Sadıkoğlu, 2002). A successful outcome in which the aim is achieved involves planning to meet the goal, fulfilling the requirements of the plan(s), and taking concrete steps toward the target (Çay, 2012). Given that, in our culture, people are generally evaluated according to the criteria of success, over time, evaluations of success have become shaped by cultural pressure. This feeling of pressure begins during the primary school years, and children in this age group are already defined as successful or unsuccessful (Baran, 1995).

Achievement goals are conceptualized as the purpose or cognitive focus of talent-related activities (Ames, 1992). According to Guan (2004), achievement goals are the phenomena explaining how individuals engage inactivity related to success and why they want to achieve what they accomplish. The basic principle of achievement goal theory is that each achievement goal influences the affective, cognitive, and behavioral reactions of individuals in situations of their success (Butler, 1992; Duda and Nicholls, 1992). Theorists of achievement goals suggest that the type of orientation chosen at the beginning of an activity creates a framework with regard to how individuals interpret and evaluate information related to achievement and their experiences in environments of achievement (Ames and Archer, 1988).

Traditionally, in initial studies, the Theory of Achievement Goals in Sport focused on two goal orientations, performance and mastery (or ego/duty; Duda and Nicholls, 1992). While terms such as "mastery orientation" and "duty-related goals" were used to express mastery in skill development, learning, or tasks in achievement goal theory, 
terms such as "performance orientation" and "ego-related goals" were employed to express the goals of skill display and superiority over others.

According to Duda and Nicholls (1992), while "performance orientation" describes goals "based on others" such as being better, more noticeable and higher ranking than others, "mastery orientation" denotes a goal orientation "based on oneself", which includes improvement over previous performance, learning new things, and mastering a task. Recent studies in other fields, however, have suggested that achievement goals are further strengthened by the inclusion of "approach incentives" and "avoidance incentives" in the standard performance/mastery classification (Elliot, 1999; Elliot and McGregor, 2001). The "2x2 Achievement Goals Model" was thus formed on the basis of "mastery approach", "performance approach", "performance avoidance" and "mastery avoidance". "Mastery approach goals" (for example, learning and development) express doing a given task as best possible or improvement over previous performance related to the task. Due to these aspects, "mastery approach goals" are more preferred and more adaptable. "Performance approach goals" incorporate the idea of surpassing others, of being superior to others. This goal orientation is only adaptive when it serves a perception of high competency. "Performance avoidance goals", on the other hand, focus on not being surpassed by others, not remaining behind others; this orientation expresses the dimension that is the least functional in the achievement motivation model. "Mastery avoidance goals", the final dimension included in the model, refer to not making mistakes, not performing worse than in the previous performance (Elliot, 1999; Elliot ve McGregor, 2001; Elliot ve Conroy, 2005). As will be understood from the above explanations, while mastery approach goals describe an adaptive dimension of achievement goals, the other three dimensions (performance approach, performance avoidance, and master avoidance goals) express non-adaptive achievement goals. Performance approach goals can only be adaptive when they contribute to creating a higher level of competence perception on the part of the individual.

Although athletes' goal orientations differ according to the characteristics described above, they nonetheless have certain common goals: athletic arenas are environments in which the participants struggle to be faster, stronger, etc., while simultaneously performing according to certain rules and declaring one side the winner and the other side loser. When contemplating the concept of "winning", the first thing that comes to mind is the result. In this context, the necessity of studying the components of feelings pertaining to winning, such as how these feelings come about and how they become entrenched, as well as what types of goals athletes set for themselves and how they discipline themselves, has become evident (Okur, 2002). While some athletes taking part in competitions in various sports may thoroughly desire to be winners, others may, in order to be a winner, be willing to rise to a higher level to improve themselves and their performance, setting their goals accordingly (İkizler, 1994). Individuals are observed to exhibit different behaviours with respect to reaching their goals. These behaviours may manifest themselves physically, mentally, and/or psychologically. Athletes may therefore be subject to psychological burden brought about by a competition as a result of the goals related to winning set for themselves and the meaning placed on winning (or losing). Internal tension may increase with the pressure of this burden, and disappointment and fear of losing may replace the desire to win (Biçer, 1998). In other words, achievement goals may be considered an important tool for the athlete to give direction to his/her goals, to give meaning to winning, to persevere, and to strive, while negative feelings may be experienced when emotions involving winning cannot be properly internalized.

Proceeding from discussion of achievement goals and perceptions of winning, this study aimed to test the relationship between the two, by first determining the achievement goals of participating female basketball players and their levels of perception of winning.

\section{Method}

\subsection{Research Model}

This study was planned as a descriptive study based on the relational survey model, with the goal of discovering the relationship between achievement goals and perception of winning. As is known, the relational screening model was devised to reveal a possible relationship between two or more variables, and to determine the degree of the relationship (Karasar, 2009).

\subsection{Participants}

The study population was composed of female basketball players competing in the Turkish Women's Basketball League during the 2015-2016 season. The sample group for the study was determined using an easily accessible sampling method. The 92 participants in the study ranged in age from 16 to 31 years; the mean age was $19.45 \pm 3.46$ and the mean

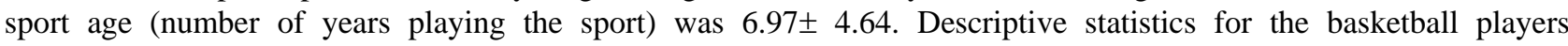
participating in the study are presented in Table 1. 
Table 1. Demographic data of the participants

\begin{tabular}{lccccc}
\hline Variables & N & Min. & Max. & Mean & St. Dev. \\
\hline Age & 92 & 16.00 & 31.00 & 19.45 & 3.46 \\
Sport age & 92 & 4.00 & 20.00 & 6.97 & 4.64 \\
\hline
\end{tabular}

\subsection{Data Collection Tools}

The personal demographic characteristics of the basketball players participating in the study were assessed using a "Personal Information Form". The "Perception of Winning Scale" and "2x2 Achievement Goals Inventory in Sport" questionnaires (see below) were used to evaluate participants' levels of perception of winning and achievement goals, respectively.

The Perception of Winning Scale for Athletes: In order to measure the perceptions of women basketball regarding winning, the "Perception of Winning Scale for Athletes" developed by Okur and Güven (2012) for Turkish athletes were used. The scale is a 5-point Likert-type self-assessment scale consisting of 10 items and one dimension. The Cronbach's alpha value for the original scale is .91 .

The first set of analyses assessed the reliability of scales. In this study, the internal consistency coefficient calculated using Cronbach's alpha was.77, indicating that the scale is reliable for this study.

$2 \times 2$ Achievement Goals Inventory in Sport: The "2x2 Achievement Goals Inventory in Sport", developed by Conroy et al. (2003) and adapted for Turkish by Kazak Çetinkalp et al. (2009), was used to determine the participants' achievement goals. The inventory, a 7-point Likert-type self-assessment scale, consists of four subscales (mastery approach, performance approach, performance avoidance, and mastery avoidance) and a total of 12 items. The Cronbach's alpha values calculated for this study vary between .73 and .98 . The results of the reliability analysis indicate that the inventory can be used for this study.

\subsection{Data Analysis}

Descriptive statistics, normality distribution tests and Pearson Moments Correlation Analysis were used to analyse the data. The significance level for statistical operations was .05.

\subsection{Data Collection Procedures}

In this study, personal information form created by the researchers was used to determine the demographic characteristics of the female basketball players. The explanatory information related to study, purpose and importance of the study has been given by the researchers. As a result of these explanations, basketball players who stated that they did not want to participate in this study were excluded from the study. Data collection tools were applied to players who volunteered to participate in this study. Data were collected in the meeting room prior to training.

\section{Results}

Descriptive statistics results calculated for the "Perception of Winning in Sport" scale and "2x2 Achievement Goals Inventory in Sport" subscales are presented in Table 2.

Table 2. Descriptive statistics of participants' scores on scale and subscales

\begin{tabular}{lccccccc}
\hline Variables & $\mathbf{n}$ & Min. & Max. & Mean & St. Dev. & Skewness & Kurtosis \\
\hline Perception of Winning & 92 & 1 & 5 & 4.67 & 0.30 & -.656 & -.663 \\
Mastery avoidance & 92 & 1 & 7 & 4.91 & 1.6 & -.751 & -.749 \\
Mastery approach & 92 & 1 & 7 & 6.02 & 1.91 & -.902 & 1.432 \\
Performance avoidance & 92 & 1 & 7 & 5.12 & 1.70 & -.823 & -.742 \\
Performance approach & 92 & 1 & 7 & 5.64 & 1.65 & -.923 & .511 \\
\hline
\end{tabular}

The results presented in Table 2 show that the participating female basketball players had a very high perception of winning. The participants had the highest achievement goal scores on the "mastery approach" subscale. The skewness and kurtosis values, which reveal whether or not data are distributed normally, are within the limits of acceptability. Taking into account the criteria that skewness values should be between +1 and -1 and kurtosis values between +2 and -1 (Huck, 2008), the values obtained for all subscales are considered to be within the desired range, and exhibit normal distribution.

Pearson Moments Multiplication Correlation analysis was performed to determine whether there was a relationship between the scores on "Perception of Winning Inventory in Sport" and the"2X2 Achievement Goals Inventory in Sport". 
The results are presented in Table 3.

Table 3. Correlation analysis results for the relationship between perception of winning scores and achievement goal scores of female basketball players

\begin{tabular}{|c|c|c|c|c|}
\hline Variables & $\begin{array}{l}\text { Perception of } \\
\text { Winning }\end{array}$ & $\begin{array}{l}\text { Mastery } \\
\text { avoidance }\end{array}$ & $\begin{array}{l}\text { Mastery } \\
\text { approach }\end{array}$ & $\begin{array}{l}\text { Performance } \\
\text { avoidance }\end{array}$ \\
\hline \multicolumn{5}{|l|}{ Perception of Winning } \\
\hline Mastery avoidance & .20 & & & \\
\hline Mastery approach & .173 & $.549 * *$ & & \\
\hline Performance avoidance & $.243^{*}$ & $.419^{* *}$ & $.558 * *$ & \\
\hline Performance approach & $.270 * *$ & $.418 * *$ & $.741 * *$ & $.756^{* *}$ \\
\hline
\end{tabular}

Correlation analysis results for the participants' "perception of winning" scores and "performance approach" $(\mathrm{r}=.243)$ and "performance avoidance" $(\mathrm{r}=.270)$ goal scores are notable in that the values indicate a low but nonetheless positive association. However, no relationship was found between the participants' perception of winning scores and "mastery goals" $(p<.05)$.

In Table 4, the results of the correlation analysis showing the relationship between the age and sport age scores of the basketball players who participated in the study, together with their scores from the scale and subscales, are presented.

Table 4. Correlation analysis results with respect to age and sport age for the scale and subscale scores of the participating female basketball players

\begin{tabular}{llllll}
\hline Variables & $\begin{array}{l}\text { Winning } \\
\text { perception }\end{array}$ & $\begin{array}{l}\text { Mastery } \\
\text { avoidance }\end{array}$ & $\begin{array}{l}\text { Mastery } \\
\text { approach }\end{array}$ & $\begin{array}{l}\text { Performance } \\
\text { avoidance }\end{array}$ & $\begin{array}{l}\text { Performance } \\
\text { Approach }\end{array}$ \\
\hline Age & .139 & -.181 & .162 & .140 & $.226^{*}$ \\
Sport age & .071 & $-.209^{*}$ & .103 & -.003 & .103 \\
\hline${ }^{*}<.05$ & & & &
\end{tabular}

As shown in Table 4, a positive correlation was found between the age of the participating basketball players and their performance approach goals $\left(\mathrm{r}=.226 ; \mathrm{r}^{2}=.051 ; p<.05\right)$. There was a negative association between sport age and mastery avoidance goals $\left(\mathrm{r}=-.209 ; \mathrm{r}^{2}=.04 ; p<.05\right)$, however no significant relationship was found between the perception of winning and age or sport age.

\section{Discussion}

The present study aimed to determine the perception of winning and achievement goals related to basketball among female players competing in the Turkish Women's Basketball League (TKBL), as well as to investigate any association between these two variables. The participants' perception of winning scores was high, and their most salient result for achievement goal orientations was for the mastery approach (Table 2). In addition, perception of winning was found to be associated with performance goals based on others (Table 3). The results also indicated that as athletes' ages increased, they intensified their focus on goals based on others, and that with increasing experience, they focused less on avoid making mistakes and not falling below the standards of previous performances (Table 4).

In this study, the high perceptions of winning exhibited by the female basketball players may be considered as a desired result. As Hayashi (1996) stated, the perception of winning in sport is thought to be a driving force, a positive inducement that allows athletes to focus on their goals. In this sense, competitions can also contribute to developing an understanding of "focusing on winning and accepting defeat" or "seeing winning and losing as a part of life". Competitions are always held to win. As such, it is inevitable that at least one party must lose in any competition. In this context, competitions will enable an enhanced understanding of the fact that winning or losing is neither the beginning nor the end, but rather both are an inevitable part of the process of striving (Erdemli, 2002). Competitions are meaningful when winning and losing are considered to be only "outcomes". More explicitly, not considering defeat to be complete failure suggests the view that there may be an opportunity for new beginnings in some cases, and that this should be explained in terms of work and effort. "Perception of winning" means that the athlete's effort to be successful in competition can be adaptable and serve to develop self-esteem when he/she persists in the face of defeat and turns toward pride in their success. However, the fact that athletes have high perceptions of winning may be perceived as 
undesirable in some situations. When winning is considered solely a result and the perception is that only the winning side is rewarded, it may also be inevitable that athletes exhibit negative behaviours. For example, Haynes (2006) associated the social and moral characteristics of student athletes and non-athletes with their goal orientations (task/ego). He concluded that the non-athletes showed more support for concepts such as justice, honesty, and responsibility compared to the athletes. While the athletes supported concepts such as teamwork and self-sacrifice, he argued that they defended dishonest and crooked actions in competition. He stated that athletes who specified ego-oriented goals exhibited such actions more frequently in order to gain superiority over others during matches (Haynes, 2006).

Researchers who work on the perception of winning in athletes have emphasized winning and success is an inevitable part of competition and so that an important goal, but should not be the only and most important (Martens, 2004; Smith \& Smoth, 2002; Thompson, 2003). For many years, the importance of winning for athletes has been debated (Smith \& Smoll, 1997). Young athletes rank winning below other participation consequences, like enjoyment of sport, social aspects of participation, enjoyment of learning new skills (Smith, et al. 1978). This inference can cause serious problems for athletes. Because, researches with athletes indicate that winning and losing have considerable affective consequences (Scanlan \& Passer, 1978, 1979; Scanlan \& Lethwaite, 1983). So that, the primary goal of sport participation should be develop desirable psychological, physical and social aspects as well as physical skills, fitness, enjoyment. Depending on these implications and researchers' findings, it is necessary to help athletes to set task oriented goals to reduce their negative emotions.

The second objective of the present study was to reveal the relationship between the perception of winning and achievement goals in female basketball players. Perception of winning is a concept that explains why athletes participate in a physical activity, why they expend so much effort to succeed at something difficult and persist over a long period of time (Hayashi, 1996). When this is taken into consideration, it is possible to purport that the feeling of winning may be a factor in athletes' exhibiting either approach or avoidance orientations (achievement goals) in competition. In fact, the findings obtained in this study revealed that athletes with high goals for winning set targets centred on performance approach and performance avoidance. This finding is crucial for explaining the nature of performance-oriented goals. In the literature, it is observed that the studies that test the relationship between achievement goals and perception of winning are quite limited. Cumming et al. (2007) showed that there is no relation between motivational climate and winning. Also, they stated that the enjoyment and commitment to sport is related to coach behaviour rather than the records of win-loss.

As is known, performance approach goals and performance avoidance goals are known "goals based on others", and athletes focused on such goals consider themselves successful when they defeat their opponents. For these athletes, the primary objectives are outcomes such as being a champion and winning a medal. High scores on the perception of winning scale are therefore an expected result for athletes who have set such goals for themselves. This goal orientation is only adaptive when it contributes to a high perception of competence. However, performance avoidance goals focus on not being surpassed by others, not falling behind others. Therefore, the positive relationship between perception of winning and performance avoidance goals is an unexpected result. This is because it is known that performance avoidance goals arise when individuals start to develop the idea they will lose the contest and appear inadequate compared to others. In this respect, performance avoidance goals are considered the least desirable and least adaptive type of achievement goals. Also, because of performance goals in sport are also related to many negative situations, they are not considered adaptive. Research has shown that performance-oriented athletes tend to value winning over fairness in sport, therefore are more likely to display lower levels of moral reasoning in sport situations in order to win (Roberts, 2001). On the other hand, mastery-oriented athletes tend to focus on themselves and fulfilling their potential, therefore are more likely to display higher levels of moral reasoning in sport situations in order to play fair (Kavussanu \& Roberts, 2001).

This present study has some limitations. First, the study relied exclusively on self report data. Second, the research sample group was somewhat limited. Third, this study focused only on the relationship between winning perception and achievement goals in basketball teams. Therefore, it may be suggested to increase the sample group and different sports branches for future studies. Also, other researchers may be advised to incorporate different variables (eg. anxiety, aggression, self esteem, burnout etc.) into the study, which may have consequences for winning perception and achievement goals. On the other hand, recommendations for coaches and adults may also be provided for the application. The coaches and the adults who are important to athletes should contribute to identifying mastery-oriented goals. It should be emphasized that winning is not the only and important goal. A number of strategies for coaches to promote incremental beliefs among athletes such as defining superiority of effort, focusing on effort and persistence, encouraging learning, facilitating struggle, providing high expectations, and promoting the value of failure. Furthermore, given that mastery-approach goals indirectly linked incremental beliefs with enjoyment, coaches and parents should avoid promoting comparison standards and instead encourage youth to strive to improve their personal development, learn skills, and have fun 


\section{References}

Ames, C. (1992). Classrooms: Goals, Structures, and Student Motivation. Journal of Educational Psychology, 84 (3), 261-271. https://doi.org/10.1037/0022-0663.84.3.261

Ames, C., \& Archer, J. (1988). Achievement Goals in the Classroom: Student's Learning Strategies and Motivational Processes. Journal of Educational Psychology, 80, 260-267. https://doi.org/10.1037/0022-0663.80.3.260

Baran, G. (1995). Çocuğun Okul Başarısını Etkileyen Faktörler, Yaşadıkça Eğitim, 38, 13-15. (Factors Affecting Child's School Success, Journal of Education for Life, 38, 13-15).

Biçer, T. (1998). Doruk Performans (Peak Performance). 2. Baskı, Beyaz Yayınları, İstanbul.

Butler, R. (1992). What Young People Want to Know When: Effects of Mastery and Ability Goals on Interest in Different Kinds of Social Comparisons, Journal of Personality and Social Psychology, 62, 934-943. https://doi.org/10.1037/0022-3514.62.6.934

Çay, M. (2012). Hayvan Olmak Günahtır: Bir Bilgelik Ansiklopedisi. Ankara. Çay Yayınları.

Çepikkurt, F., \& Uluöz, E. (2017). Predictive power of group cohesion and perceived motivational climate for collective efficacy perception in the football teams. Sport \& Society/Sport si Societate, 17(1).

Comeig, I., Grau-Grau, A., Jaramillo-Gutiérrez, A., \& Ramírez, F. (2016). Gender, self-confidence, sports, and preferences for competition. Journal of Business Research, 69(4), 1418-1422. https://doi.org/10.1016/j.jbusres.2015.10.118

Conroy, D.E., Eliot, A.J., \& Hofer, (2003). SM. A 2x2 achievement goals questionnaire for sport: Evidence for factoria linvariance, temporal stability, and external validity. Journal of Sport \& Exercise Psychology, 25, 456-476. https://doi.org/10.1123/jsep.25.4.456

Cumming, S. P., Smoll, F. L., Smith, R. E.,\& Grossbard, J. R. (2007) Is Winning Everything? The Relative Contributions of Motivational Climate and WonLost Percentage in Youth Sports, Journal of Applied Sport Psychology, 19(3), 322-336. https://doi.org/10.1080/10413200701342640

Duda, J.L., \& Nicholls, J. G. (1992). Dimensions of achievement motivation in schoolwork and sport. Journal of Educational Psychology, 84, 290-299. https://doi.org/10.1037/0022-0663.84.3.290

Elliot, A. J. (1999). Approach and avoidance motivation and achievement goals. Educational Psychologist, 34, $169-189$. https://doi.org/10.1207/s15326985ep3403_3

Elliot, A. J., \& Conroy, D.E.(2005). Beyond the dichotomous model of achievement goals in sport and exercise psychology. Sport and Exercise Psychology Review, 1, 17-25.

Elliot, A. J., \& Mc Gregor, H. A. (2001). A 2x2 achievement goal framework. Journal of Personality and Social Psychology, 80, 501-519. https://doi.org/10.1037/0022-3514.80.3.501

Erdemli, A. (1992). Temel Sorunlarıyla Spor Felsefesi (Sports Philosoph with Basic Problems), E-Yayınları, İstanbul.

Guan, J. (2004). Achievement Goals among High School Students in Physical Education. Yayınlanmamış Doktora Tezi, Texas A\&M University, Office of Graduate Studies, Texas.

Hayashi, C. T. (1996). Achievement Motivation Among Anglo American and Hawaiian Physical Activity Participants; Individual Differences and Social Contextual Factors; Journal of Sport and Exercise Psychology; 18(2), $194-215$. https://doi.org/10.1123/jsep.18.2.194

Haynes, F. (2002). Eğitimde Etik. Çev: Semra Kunt Akbaş. İstanbul: Ayrıntı Yayınları.

Huck, S. W. (2008). Reading statistics and research (5rd edition). New York: Addison Wesley Longman.

İkizler, C. (1994). Sporda Başarının Psikolojisi. İstanbul: Alfa Yayınevi; 45-47, 62-64.

Karasar, N. (2009). Bilimsel araştırma yöntemi(Scientific Research Model). Ankara: Nobel Yayın Dağıtım.

Kavussanu, M. \& Roberts, G. C. (2001). Moral functioning in sport: An achievement goal perspective. Journal of Sport and Exercise Psychology, 23, 37-54. https://doi.org/10.1123/jsep.23.1.37

Kazak Çetinkalp, Z. (2009). Sporda Hür İrade Kuramı ve Başarı Hedefi Kuramının Değerlendirilmesi. Doktora Tezi, Ege Üniversitesi Sağlık Bilimleri Enstitüsü, İzmir. (Evaluation of Self Determination Theory and Achievement Goal Theory in Sport. Doctoral Thesis, Ege University Health Sciences Institute, İzmir)

Okur, K. ( 2002). Sporcuların Kazanmaya Yönelik Algıları. Yayınlanmış Yüksek Lisans Tezi. Gazi Üniversitesi Sağlık Bilimleri Enstitüsü, Ankara. (Assessment on Winning -Oriented Perception of Athletes. Publissed Master Thesis, 
Gazi University Health Sciences Institute, Ankara).

Rottensteiner, C., Tolvanen, A., Laakso, L., \& Konttinen, N. (2015). Youth athletes' motivation, perceived competence, and persistence in organized team sports. Journal of Sport Behavior, 38(4), 1-18.

Sadıkoğlu, G. (2002). Aile Psikolojisi ve Eğitimi (Family Psychology and Education). Eskişehir. Anadolu Üniversitesi Yayınları.

Scanlan, T. K., \& Lethwaite, R. (1984). Social psychological aspects of competition for male youth sport participants: I. Predictors of competitive stress. Journal of Sport Psychology, 6, 208-226. https://doi.org/10.1123/jsp.6.2.208

Scanlan, T. K., \& Passer, M. W. (1978). Factors related to competitive stress among male youth sports participants. Medicine and Science in Sports, 10, 103-108.

Scanlan, T. K., \& Passer, M. W. (1979). Sources of competitive stress in young female athletes. Journal of Sport Psychology, 1, 151-159. https://doi.org/10.1123/jsp.1.2.151

Sheehan, R. B., Herring, M. P., \& Campbell, M. J. (2018). Associations between motivation and mental health in sport: A test of the hierarchical model of intrinsic and extrinsic motivation. Frontiers in psychology, $9,707$. https://doi.org/10.3389/fpsyg.2018.00707

Smith, R. E., \& Smoll, F. L. (1997). Coaching the coaches: Youth sports as a scientific and applied behavioral setting. Current Directions in Psychological Science, 6, 16-21. https://doi.org/10.1111/1467-8721.ep11512606

Smith, R. E., Smoll, F. L., \& Curtis, B. (1978). Coaching behaviors in Little League Baseball. In F. L. Smoll, \& R. E. Smith (Eds.), Psychological perspectives in youth sports (pp. 173-201). Washington, DC: Hemisphere.

\section{Copyrights}

Copyright for this article is retained by the author(s), with first publication rights granted to the journal.

This is an open-access article distributed under the terms and conditions of the Creative Commons Attribution license which permits unrestricted use, distribution, and reproduction in any medium, provided the original work is properly cited. 